\title{
Exploration methods for granitic natural stones - geological and topographical aspects from case studies in Finland
}

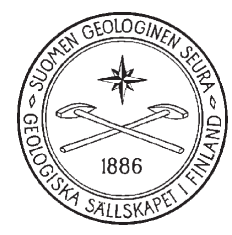

\author{
Olavi Selonen ${ }^{1 *}$, Carl Ehlers ${ }^{1}$, Hannu Luodes $^{2}$ \\ AND PAAVO HÄRMÄ3 \\ ${ }^{1}$ Abo Akademi University, Department of Natural Sciences, \\ Geology and Mineralogy, FI-20500 Turku, Finland \\ ${ }^{2}$ Geological Survey of Finland, P.O. Box 1237, FI-70211 Kuopio, Finland \\ ${ }^{3}$ Geological Survey of Finland, P.O. Box 96, FI-02151 Espoo, Finland
}

\begin{abstract}
Regional and local geological constraints for location of natural stone deposits in glaciated terrains of southern and central Finland have been studied and applied to practical exploration for natural stone. A list of geological and topographical aspects to be considered in exploration, is presented. Important aspects refer to: 1. Regional geology of the target area. 2. Magmatism (type and structure of intrusion, relative time of pluton emplacement). 3. Metamorphism (grade, mineral composition, parent material). 4. Deformation (lineaments, shear zones, folding, fault zones, fracture zones, shape preferred mineral orientations), and 5. Topography (relative elevation, micro topography). The proposed aspects can be used as geological guidelines in exploration for granitic natural stones.
\end{abstract}

Keywords: building stone, dimension stone, ornamental materials, granite deposits, mineral exploration, glaciated terrains, Finland

* Corresponding author email: olavi.selonen@abo.fi

Editorial handling: Joonas Virtasalo

\section{Introduction}

Traditionally, exploration for natural stone has been done by experienced quarrymen with no formal geological education. Their methods have included observations on road cuts, stone foundations and ruins, discussions with local people etc. Geologists, on the other hand, have shown little interest in exploration for natural stone, and there is not much literature on geological constraints on occurrence or quality of natural stone deposits (cf. Heldal \& Lund, 2000; Selonen et al., 2000; Carvalho et al., 
2008; Heldal et al., 2008).

As a result of the sparse systematic geological research in connection with natural stone exploration, scientifically based methods for (regional) explorations are lacking. In the case of site investigations developed techniques are used (geo-radar, fracture mapping, drilling etc.). Compared to the well-developed methodology in ore (or oil) prospecting including geophysical, geochemical, and geological methods based on the latest geological knowledge, the prospecting is on an elementary level. Of course, we have to acknowledge the difference in economical importance between the industries, but the use of geological knowledge is essential in both cases.

We have studied selected Proterozoic rock areas of different geological settings in southern and central Finland (e.g. Selonen, 1998, 2008; Selonen et al., 2000, 2005, 2011, 2012; Karell, 2006; Nyman, 2007; Meriluoto, 2008; Arponen et al., 2009; Karell et al., 2009). The studies have been focused on granitic and metamorphic rocks (granites in a commercial sense) with the aim of defining geological constraints for the localization of natural stone deposits, and of identifying geological environments with potential for the occurrence of rocks suitable for production. Another aim has been to create and develop geological exploration methods and models for a systematic search of natural stone. Selected study areas are presented in this article.

We have also been involved in practical exploration surveys and detailed site investigations in southern, central, and eastern Finland. These investigations have been done mainly in connection with the above mentioned studies on prospecting methods or as parts of regional projects conducted by the Geological Survey of Finland (GTK) (e.g. Härmä, 1987; Selonen, 1994, 1998; Selonen \& Ehlers, 1998a; Luodes, 1999, 2003, 2008; Härmä \& Selonen, 2000, 2008; Luodes et al., 2000; Härmä et al., 2001, 2006). A map of geological potential for natural stone in southern and central Finland is presented in Fig. 1.

In this paper, based on the studies of prospecting methods, and supported by the results of the exploration surveys, we propose a selection of geological and topographical aspects relevant for the exploration of granitic natural stones. A collection of practical hints for the exploration has not been published before. In the article we compile previous published and recent unpublished material. This paper is a part of our recent series of publications on geology of natural stone deposits (see, Selonen et al., 2011, 2012).

\section{Geological aspects in exploration for natural stone}

The formation of rocks suitable as natural stone deposits is connected to common geological processes, easily addressed by ordinary geological investigation methods. The location of all natural stone deposits is controlled by geological factors. Our studies suggest controls such as: the regional geological setting, the magmatic history of an intrusion, its age and relation to deformations (Selonen, 1998; Selonen et al., 2012), petrology and preferred mineral alignments (including colour homogeneity and appearance) (Selonen, 1998; Selonen et al., 2000, 2011; Arponen et al., 2009), metamorphic grade (Luodes et al., 2000; Selonen et al., 2000), brittle deformation, sheeting and shearing (Selonen, 1998; Selonen et al., 2000; Meriluoto, 2008). Heldal et al. (2008) recognize the importance of, e.g. magmatic layering and mineral orientation as well as discolouration as geological features important for the quality of natural stone.

No single factor alone controls the localization of natural stone deposits, rather, it is by a favourable combination of several geological features interacting on a regional and local scale, that a rock of commercially viable quality is produced (see also Heldal \& Lund, 2000; Carvalho et al., 2008; Heldal et al., 2008).

By identifying combinations of geological factors important for the location of the natural stone deposits, we can define geological environments with potential for deposits and make prognoses for finding them. This knowledge can be applied to practical exploration for natural stone. In recent papers (Selonen et al., 2011, 2012) we have reported 
two specific case-studies on the geological constraints for the location of deposits. In those areas we have constructed local intrusion histories, forming a base for the creation of a geological exploration model for further prospecting. We suggest that the creation of such models should be included in the exploration process when possible. When that is not possible we present here a set of essential geological and topographical aspects which we have found relevant in exploration for natural stone. These aspects are by definition "simple" and easy-to-use as such, without a thorough knowledge of the geological situation of the target area. This list can serve as guidelines or "geological tools" for a systematic identification of potential target areas based on qualified geological knowledge.

In our work, we consider coherent rocks which can be quarried into blocks and can be internationally marketable. The homogeneity of the appearance (amount of colour variations, veins, inclusions etc.) and the soundness of the prospect (density of fractures) are the most important criteria for such rocks in order to qualify as natural stone (e.g. Shadmon, 1996; Selonen et al., 2000; Selonen, 2003; Heldal \& Arvanitides, 2003; Bradley et al., 2004; Luodes, 2008).

\subsection{Geology and regions of natural stone}

The occurrence of rock qualifying as natural stone is controlled by the regional geological history of target areas. Each area has its own geological potential for natural stone deposits. An overview of the regional geology helps the researcher to divide the target area into smaller subareas at an early stage in the exploration. A map of the potential for natural stone in the different geological regions of the Proterozoic rocks in southern and central Finland can serve as a large scale example (Fig. 1).

The anorogenic rapakivi granites (1650-1540 $\mathrm{Ma})$ in southern Finland occur as four major and several smaller batholiths and stocks (Rämö \& Haapala, 2005) (Fig. 1). All batholiths and most smaller stocks are composite intrusives consisting of smaller intrusions with a variety of different undeformed granite types, post-dating regional ductile deformations (e.g. Rämö \& Haapala, 2005). The locations of natural stone deposits in the rapakivi batholiths are almost solely constrained by the local magmatic history of the plutons (Selonen et al., 2011). Regionally, the batholiths are sparsely fractured and homogeneous (to texture and colour), and have the highest geological potential for natural stone among the Proterozoic rocks. 85-90 \% of all granite production in Finland, the largest quarries, and the largest block sizes come from the rapakivi granite areas (P. Jauhiainen, pers. comm. 2013). Brown, red, and green granites as well as associated black anorthosites are the most important stone qualities today.

The Central Finland Granitoid Complex (CFGC) (Fig. 1) comprises different synkinematic intrusions (1890-1880 Ma), mainly consisting of foliated coarse-grained granites and granodiorites ranging in composition from gabbros to granites (Nironen, 2005). Undeformed or weakly foliated postkinematic intrusions (1885-1870 Ma) are found around the margins of the Complex (Selonen \& Ehlers, 1996; Nironen et al., 2000; Nironen, 2005). The locations of present and potential natural stone deposits are mainly controlled by the magmatic history of the intrusions (Selonen, 1998; Selonen et al., 2000, 2011, 2012). As a whole, the CFGC holds a good geological potential for natural stone, the postkinematic intrusions being the most promising sites within the complex.

The South Finland Migmatite Zone (SFMZ) (Fig. 1) is characterized by granite sheets with intense and penetrative subhorizontal regional deformation (Ehlers et al., 1993; Selonen \& Ehlers, 1998b; Levin et al., 2005; Väisänen et al., 2012). The structurally gently dipping sheets expose large areas of granite outcropping along the present subcambrian peneplane. The wide areas of exposed granite include sites with prospects for natural stone, see Figure 5. The regional transpressional deformation (e.g. Ehlers et al., 1993) has produced gently dipping mineral orientations, which affect the sheeting and fracturing in the plutons, and is a major factor for the location of the deposits (Selonen, 1998). The geological controls on the 


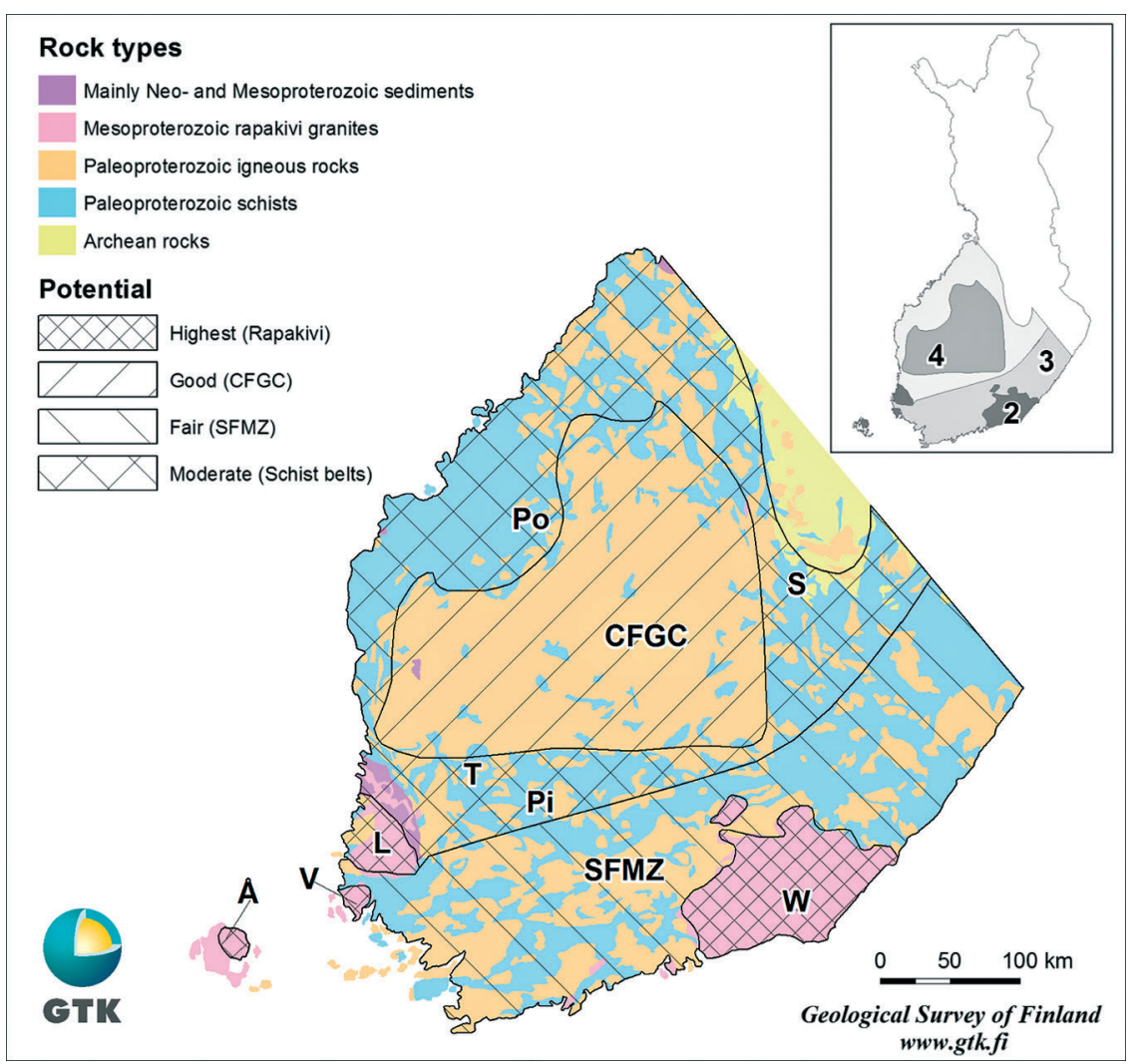

Fig. 1. Geological potential for natural stone in the Proterozoic rocks of southern and central Finland. The map is based on our studies on prospecting methods and on data produced in connection with the regional explorations by the Geological Survey of Finland (GTK). Methods and target areas of the GTK investigations are described by Luodes (2008). The environmental and infrastructural constraints for exploitation are omitted. See text for further explanation. CFGC $=$ Central Finland Granitoid Complex, SFMZ = South Finland Migmatite Zone, W = Wiborg rapakivi granite batholith, $L=$ Laitila rapakivi granite batholith, $V=$ Vehmaa rapakivi granite batholith, $\AA=$ Åland rapakivi granite batholith, $T=$ Tampere Schist Belt, $\mathrm{Pi}=$ Pirkanmaa Schist Belt, $\mathrm{S}=$ Savo Schist Belt, and Po = Pohjanmaa Schist Belt. Geological map (c) Geologian tutkimuskeskus, Basemaps: (C) National Land Survey of Finland. Inset: locations of sub-areas in Fig. 2, 3 and 4.

location of potential areas for natural stone are connected to the local history of deformation and metamorphism (Selonen, 1998; Selonen et al., 2000). As a whole, the SFMZ-zone has a fair geological potential for natural stone, but it hosts local high-grade metamorphic, partially melted migmatite areas with good potential for multicoloured granitic natural stones.

The granitoids of the schist belts to the north of the SFMZ-zone and those around the CFGC (Kähkönen, 2005) (Fig. 1) are intruded mostly as diapiric plutons often composed of several magmatic phases (Nironen, 2005). The regional deformation in the intrusions is relatively weaker than that in the SFMZ-zone (Ehlers et al., 1993, Selonen \&
Ehlers, 1996; Nironen, 2005). The intrusion history and distribution of the magmatic phases is the controlling factor for localization of granites suitable as natural stone (Selonen, 1998). As a whole, the schist belts hold a moderate geological potential for natural stone, but certain individual intrusions (green/red/brown), high-grade metamorphic blocks (for multi-coloured stones), and sedimentary beds for schist prospects, can have a good potential.

National exploration projects are often financed by regional authorities and municipalities using local and international funds (e.g. Luodes, 2008). The selection of target areas is based on administrative, not geological priorities. Our results, however, indicate that a geological target selection based on 
suitable lithologies could be a more fruitful starting point for successful exploration (cf. e.g. Heldal \& Lund, 1995; Egesi \& Tse, 2011).

\subsection{Magmatic aspects \\ 2.2.1. Type of intrusions}

Most intrusions in our investigations have been composite plutons with several intrusion phases (felsic and mafic), and a few sheet-like intrusions. In the composite plutons, natural stone deposits and potential sites are found in all magmatic phases regardless of their internal relative time of emplacement (Selonen, 1998, Selonen et al., 2000). However, late phases rich in aplitic and pegmatitic rest melts can be so inhomogeneous and densely fractured, that industrial quarrying is impossible (Selonen, 1998, Selonen et al., 2000). In certain mafic layered and dyke-like intrusions, the detailed mineral composition of the phases controls their feasibility (Härmä, 1991, Uusinoka et al., 1996).

Magmatic phases show different appearances and colours. Common colours (red, grey, brown, green) can be found in the felsic phases. In exploration, it is important to observe that composite intrusives can host mafic magmatic components, which could have potential for the popular and always sought after black stone ("black granites"). Because of magma mingling, the felsic phases in these plutons may have mafic enclaves, regarded as flaws in the commercial appearance of the stone (e.g. Selonen et al., 2012).

In composite batholiths and stocks all the magmatic phases could have potential for natural stone and must be considered in the exploration. A thorough and detailed geological and lithological field investigation may be needed for the identification of the different magmatic phases and their sometimes only slightly different appearances and colours (Selonen et al., 2005; Arponen et al., 2009; Selonen et al., 2011; cf. also e.g. Glazner et al., 2004). These small differences are easily overlooked in the field, but in cases represent the difference between economically more interesting and less interesting rock appearances. Even small and seemingly simple intrusions can be composed of several intrusion phases.

A detailed mapping can reveal different phases and give geological and lithological constraints for the location of present and potential stone deposits (Arponen et al., 2009) (Fig. 2). For instance, detailed lithological mapping (Fig. 2A) showed that anorogenic anorthosite intrusions consist of several mafic rock types. The leucogabbronorite, being the
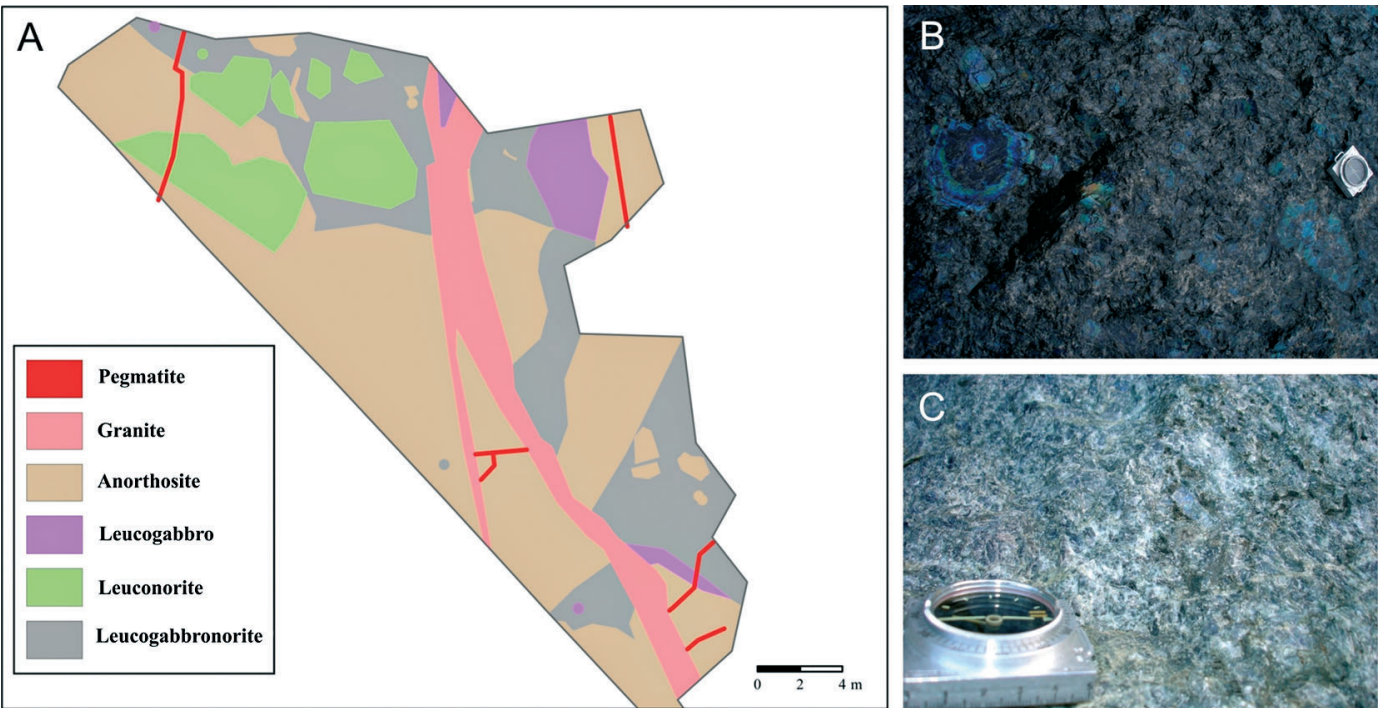

Fig. 2. Lithological control of spectrolite deposits in anorogenic anorthosite intrusions. A. Detailed lithological map of a part of an anorthosite intrusion. B. Spectrolite in the leucogabbronorite. C. Spectrolite in the leuconorite. For location of the area, see inset in Fig.. 1. Modified from Arponen et al. (2009). 
most common rock type with the highest content of spectrolite, has the highest potential for exploitation. The spectrolite is well-crystallized with large crystals (Fig. 2B) and iridescences in all spectral colours in the dark leucogabbronorite. In contrast, e.g. the spectrolite in the leuconorite is lightcoloured and less iridescent (Fig. 2C), and thus less suited for exploitation according the fashion criteria of today.

\subsubsection{Relative time of pluton emplacement}

Intrusions appear at different times in relation to the surrounding ductile regional deformations. Plutons in our studies include pre to postkinematic and anorogenic intrusions. Late and postkinematic undeformed plutons and anorogenic intrusions (e.g. rapakivi granites) generally have a homogeneous structure and texture, and a lower density of fractures than more deformed intrusions (Selonen, 1994, 1998; Selonen \& Ehlers, 1998a; Härmä, 2001; Härmä et al., 2006). On average, it is common to find at least 2-3 meter average spacing of horizontal and vertical fractures in the rock types of these undeformed intrusions (Härmä \& Selonen, 2008), implying that prospects with vertical fracturing of up to 10 meters spacing can be found (Selonen et al., 2011). In deformed syntectonic intrusions it is challenging to find prospects with a fracture spacing of 2-3 meters (Selonen \& Ehlers, 1998a).

The late to posttectonic/anorogenic plutons have a high potential for rock varieties suitable for natural stone. They are sparsely fractured and homogeneous and should be investigated in all regional geological settings. The relative time of pluton emplacement can be used as an indicator when searching for plutons with a sparse fracturing and a homogeneous structure on a regional scale.

\subsubsection{Level of exposure}

The level of exposure through the granite intrusions also has an important influence on the industrial suitability of the rocks.

Most of the SW part of the large and well- exposed rapakivi granite batholith on the Åland Islands (Fig. 1) consists of beautifully coloured porphyritic and fine-grained granites. However, they belong to the upper parts of the large granite batholith and consist of superficial intrusions, very fractured and with little potential for natural stone prospects. The NE parts of the same batholith are coarse-grained well-crystallized but dull coloured pyterlites apparently representing a deeper section with coarse-grained intrusions, sparsely fractured and well-suited for quarrying (Selonen et al., 2011). This is the reason why the western part of the Alland rapakivi batholith with strongly coloured rocks has only a limited potential for finding natural stone in contrast to most other areas of rapakivi in southern Finland which show deeper sections and have a good potential (Fig. 1).

\subsection{Metamorphic aspects}

In addition to granitic rocks, migmatitic rocks have an economic potential as raw material for multicoloured natural stone. The quarries and prospects with this popular and desirable product occur mainly within areas of high grade (granulite facies) metamorphism (Fig. 3) (Selonen, 1988, 1994; Selonen \& Ehlers, 1998a; Luodes et al., 2000, 2006; Selonen et al., 2000; Härmä, 2001).

The deposits in the high grade areas consist of garnet-cordierite gneisses, granites or gneissose granites. The garnet-cordierite gneisses are highly metamorphosed metapelites with a paleosome consisting mainly of garnet, cordierite and plagioclase. The amount of biotite is low, and thus not limiting the use of the rocks as natural stone. The neosome is rich in K-feldspar and quartz. The proportions of paleosome and neosome vary and the amount of neosome can be as high as $50 \%$ of the total volume. The medium and coarse-grained potassium-rich granites are intensely red and include "ghost-like" restites of mica gneiss and clusters of garnet or cordierite. The gneissose granites are medium-grained red-grey granodioritic igneous rocks with approx. $40 \%$ coarse-grained granite neosome.

In our case study (Fig. 3), metamorphism in the area is progressive, with increasing grade from 

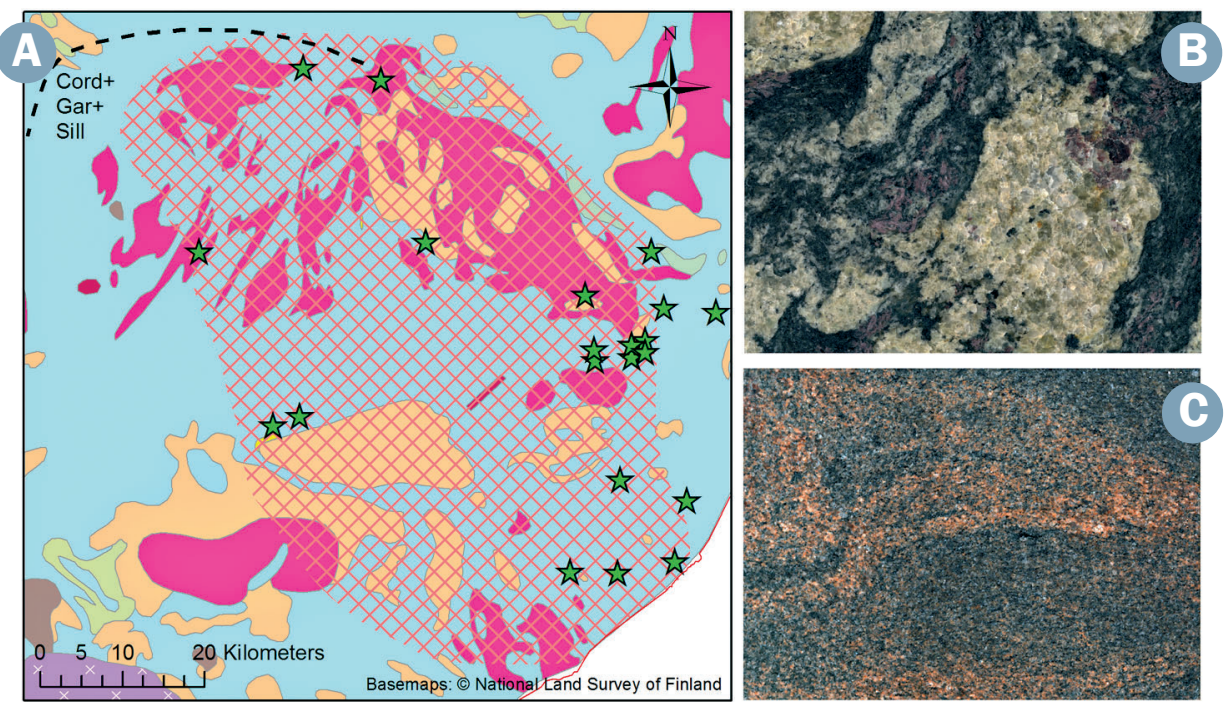

Fig. 3. Metamorphic control of the location of natural stone deposits. A. Geological map of the study area. B. Migmatite from a pelitic sedimentary parent rock. C. Migmatite from an igneous parent rock. Cord $=$ Cordierite, Gar = Garnet, Sill = Sillimanite. For location of the area, see inset in Fig. 1. Modified from Korsman et al. (1988), Selonen (1988), Luodes et al. (2000), Selonen et al. (2000), and Härmä et al. (2006). the northwest to the southeast, reaching granulite facies conditions in the southeast (Fig. 3A). The main rock types are metapelites and potassium granite. The most common types of metapelites are mica schists and mica gneisses. They are strongly migmatized and partially melted, with coarse potassium granite forming veined gneisses. In the northwestern parts of the area mica schists have preserved some primary sedimentary structures while in the granulite they are all but absent. Natural stone deposits are found mainly in garnet-cordierite gneiss (Fig. 3B) in the area of the highest metamorphic grade.

The parent material for the metamorphic rocks varies from sedimentary to igneous (Fig. 3B,C). The sedimentary facies varies from psammitic (greywackes as source rocks) to pelitic (mudstones as source rocks). Partial melting is more pervasive in pelitic rocks under high grade conditions compared to that of the psammitic rocks, and they are thus a better source for commercial natural stone. Fracturing is denser in the psammitic rock types because of local competence differences (cf. Luodes et al., 2000). Igneous parent materials produce good sparsely fractured natural stones, although the paleosomes can include more cracks than the neosomes.

Common for all these rock types is the strong partial melting and almost total homogenization of the parent material, giving the rocks technical features comparable to granites and a desirable flame-like appearance (Fig. 3). The metamorphic grade is a key indicator in exploration for multicoloured granitic natural stone deposits.

\subsection{Deformation-related aspects 2.4.1. Weakness zones and folding}

The exposed bedrock peneplane is typically fragmented into coherent blocks bordered by shear zones, fault zones and fracture zones (Fig. 4). These zones are among the most important aspects indicating localization of good natural stone prospects in all kinds of geological domains (Selonen, 1998; Selonen et al., 2000, 2011; Härmä, 2001; see also Loorents, 2000; Shekov, 2008; Heldal et al., 2008; Sousa, 2010; Lopes, 2012; Ivanov \& Shekov, 2012). Identification of sound and sparsely fractured blocks is thus a very important task in all geological explorations for natural stone. 

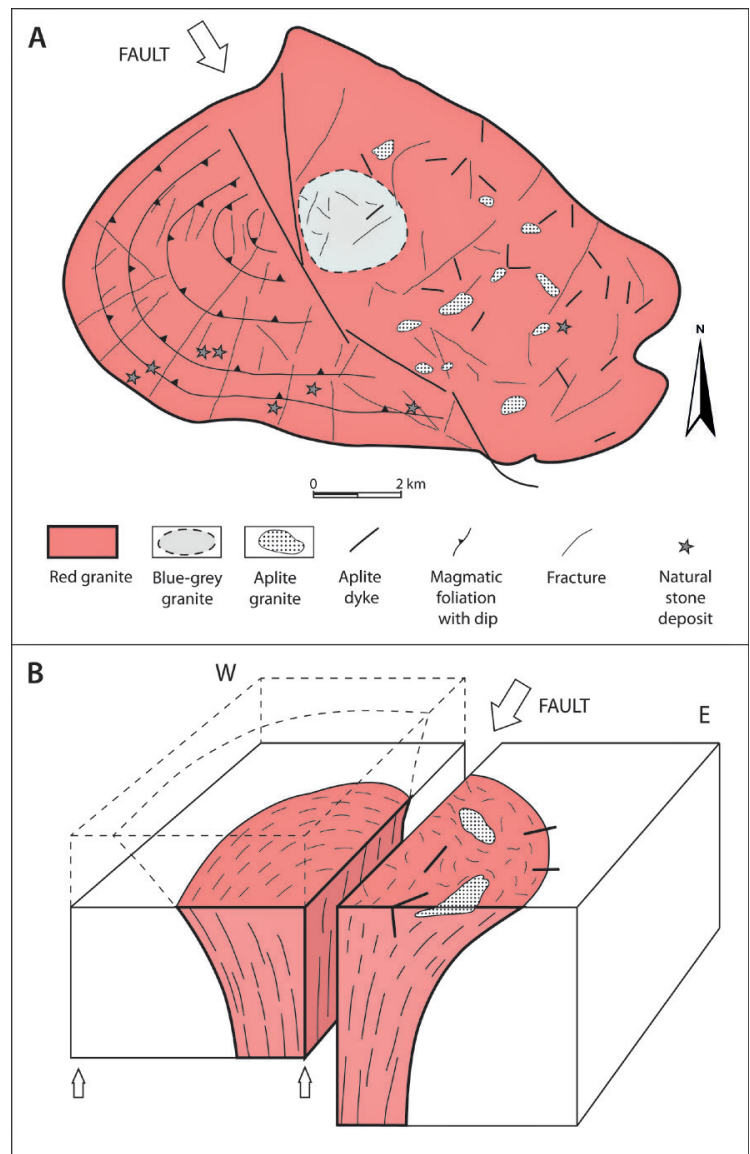

Fig. 4. Tectonic control of the location of natural stone deposits in a posttectonic granite batholith. A. Geological map of the batholith. A regional fault zone cuts the batholith into two halves. B. West-side-up movement of the batholith along the central fault zone. For location of the area, see inset in Fig. 1. Modified from Selonen (1998) and Selonen et al. (2000).

Episodes of deformation commonly reactivate old inherited zones of weakness leaving the areas between them less deformed and relatively sparsely fractured, indicating suitable areas for natural stone. Earlier weakness zones often control emplacement of later intrusions.

By observing shear zones and major fractures (on geological and topographical maps) the target area can easily be subdivided into smaller blocks with varying potential for natural stone. The blocks can be identified from a regional scale down to a local scale (Fig. 4A), and the local fracturing often border the individual deposits (Fig. 4A). Shear zones and fault zones frequently separate areas of different metamorphic grades at the present level of erosion (Selonen, 1998; Selonen et al., 2000; see also Hölttä, 1995). Areas of high metamorphism and partial melting are in a key position when prospecting for multi-coloured granitic natural stones.

Selonen et al. (2000) report an example of a vertical normal fault through a granite batholith, exposing a deeper section with homogeneous granite of good economical potential (and quarries) on one side of the fault and a shallow part with heterogeneous pegmatite and aplite veined granites on the other side (Fig. 4). A NNW-SSE trending regional fault zone cuts the batholith into two halves (Fig. $4 \mathrm{~A})$. The western half comprises sparsely and regularly fractured red granite with a well-developed, penetrative, steep, and concentric foliation. In contrast, the eastern half is characterized by intrusions of late magmatic aplites and pegmatitites into the red granite. The magmatic foliation in the eastern half is poorly developed and the late brittle fracturing on outcrops is dense (not visible on the figure in this scale). The late melts have intruded as sheets and dykes, which are too densely fractured to be quarried as natural stone. The location of the natural stone deposits in the western part of the batholith can be explained by the late geological history of the pluton (Fig. 4B). The west-side-up movement along the central fault zone exposes deeper crustal levels of more homogeneous and sparsely fractured red granite.

Ductile deformation or shearing can also produce a homogeneous structure over a wide zone, giving the rock an interesting "welded" texture and technical features suitable for commercial quarrying (Selonen, 1998).

Folding and faulting expose different levels of intrusions at the present peneplane (Selonen, 1998; Selonen et al., 2000, 2011, 2012; see also Carvalho et al., 2008; Lopes, 2012). The sub-horizontal migmatite sheets in southern Finland lie parallel to the peneplane, and expose large areas of raw material for natural stone as represented on Fig. 5A. Further southwards the sheets are folded with axial planes perpendicular to the peneplane and consequently less exposed and less accessible for easy quarrying 


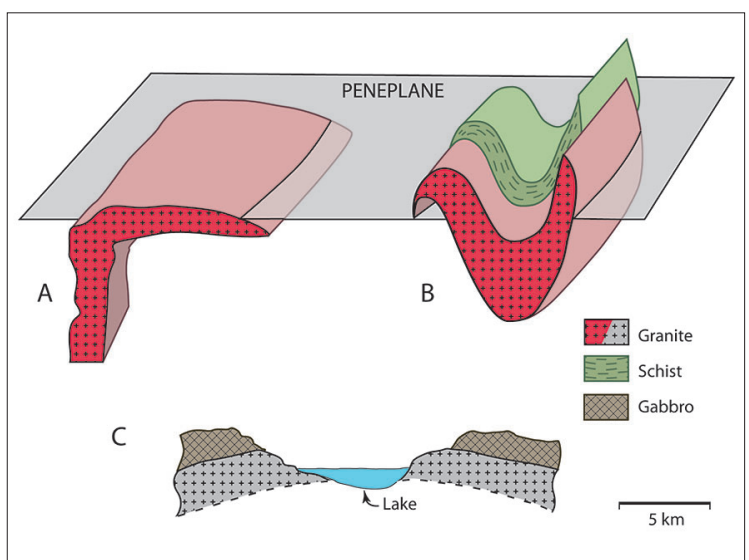

Fig. 5. Three simplified examples of granite exposures in relation to the sub-cambrian peneplane of southern Finland. A. Lateorogenic granite sheet, largely exposed along the peneplane. B. Folded granite sheets are less exposed at the present surface. C. Profile of a late synkinematic layered granite batholith. Topographical depression around a lake exposes the subhorizontal layer of grey granite with good natural stone properties. Vertical scale exaggerated. Based on localities described in Aurola (1967), Ehlers et al. (1993), Selonen et al. (1996, 2012), Selonen (1998), Stålfors \& Ehlers (2006), and Väisänen et al. (2012).

(Selonen, 1998; Selonen et al., 2012) (Fig. 5B).

The structural position of intrusions and their relation to the exposed peneplane controls the amount of exposure and influences the chance of finding rocks with potential for natural stone deposits (Fig. 5).

\subsubsection{Shape preferred mineral orientations}

Shape preferred mineral orientations (SPOs) (see, e.g. Prrikryl, 2006) are important aesthetical and technical features of rocks with economical potential for natural stone. They can control the splitting properties of rocks (Heldal et al., 2008) and their colour (Heldal et al., 2008) as well as their physical properties (e.g. Heldal \& Lund, 2000; Cuccuru et al., 2008). Our studies suggest a correlation between the SPOs, sheeting and topography (Selonen, 1998).

The rock texture affects the sheeting of the bedrock and as consequence also the topography (Selonen, 1998). Well-developed subhorizontal foliations and lineations are associated with a welldeveloped sheeting and flat topography, which are less pronounced in areas with weak fabrics. Subhorizontal SPOs often produce a dense sheeting close to the rock surface, while rocks with a subvertical SPO often seem to have a more spaced sheeting (Selonen, 1998). In the limbs of some (regional) folds we can find well-developed SPOs, with regular fractures, indicating prospects for natural stone while the hinges are associated with more massive rock with properties less suited for natural stone due to irregular fracturing (Selonen, 1998). The type of SPOs can also give some very rough indications as to the suitability of a deformed rock for natural stone: $\mathrm{L}>\mathrm{S}$-tectonites seem to have a better potential for natural stone than the $\mathrm{L}<\mathrm{S}$ tectonites (rocks with a single linear structure are homogeneous in sections perpendicular to the lineation) (Selonen, 1998).

These relationships can be important in exploration, but complementary data is required. For example, if observations on gently dipping lineations and foliations are found on a geological map, this data must be combined with local topographical data: if the (micro) topography is flat, we could expect a well-developed sheeting (and possibly a potential site). In exploration, these connections must be confirmed by field inspection.

\section{Topographical aspects in exploration for natural stone}

There is a relationship between topography, sheeting, fracture zones, and the general soundness of rock (its suitability for natural stone) in the glacially polished rocks on the peneplane of southern and central Finland. The maximum elevation of our study areas is $250 \mathrm{~m}$ and the relative differences in elevation are a few tens of metres. The local smallscale variations in topography are often less than ten metres but they can give an indication of the prospects for natural stone. An uneven and hilly surface indicates a broken and jointed rock surface. For higher topographies, see e.g. Heldal et al. (2008) and Carvalho (2008). 
Two main cases (Figs. 6A and B) of relationships between sheeting and topography can be distinguished (Selonen, 1998; Selonen et al.; 2011). Areas of granitic or homogeneous migmatitic rocks with well-developed sheeting are characterized by a flat (rounded) micro topography (semi-quantitatively indicated on topographic maps by relatively simple and few 5 and 2.5 meter contour lines per area) (Fig. 6A). This micro topography indicates positive prospects for extracting regular blocks. A hilly micro
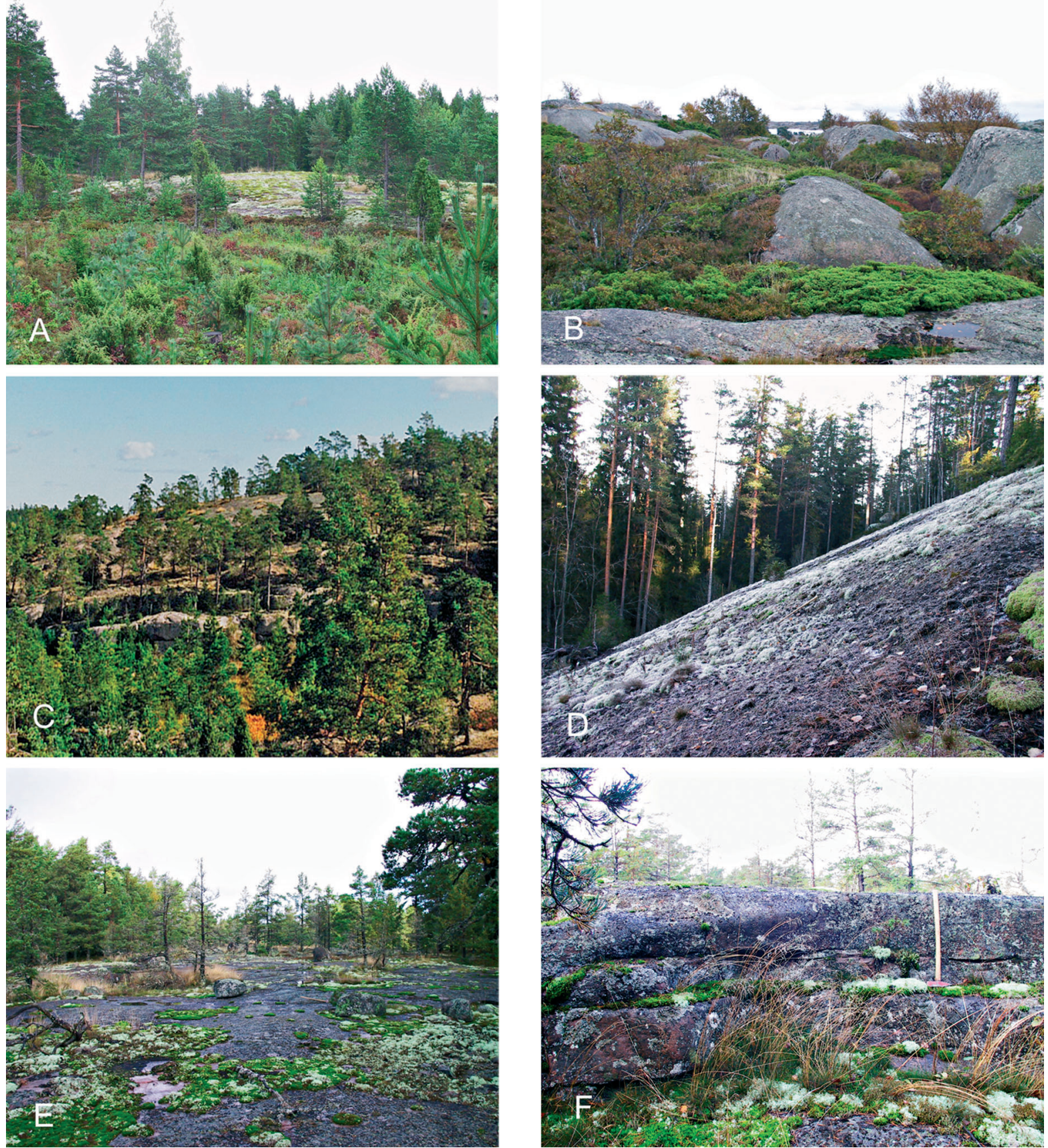

Fig. 6. Topographies showing features important for the exploration of natural stone. A. Flat and rounded topography. B. Hilly micro topography. C. Regularly shaped, terraced outcrop of granite. D. Strong inclination of the sheeting joints. E. Flat and low topography. F. Dense sheeting near the rock surface (same outcrop as in E). 
topography (many and complicated micro contour lines per area) suggests irregular jointing and a lack of regular sheeting (Fig. 6B). Natural stone can be quarried, but the extractable blocks will be irregular in shape due to the wedgy jointing.

The best indicators for areas with potential for natural stone are relatively high and large plateaulike terraced topographies, standing 25-30 meters over the surrounding terrain (Selonen, 1998; Selonen et al., 2011) (Fig. 6C). The plateaus are often bordered with wide and glacially plucked vertical fracture zones, forming topographical lows. These topographies involve a large volume of usable and easily accessible natural stone material, and signal localities with potential for natural stone. However, in cases, in these large hills, sheeting joints may be inclined (Fig. 6D) with an undesirable angle between the joints and the possible future horizontal quarry levels, diminishing the usability of the prospect.

Granite with a very wide spacing of vertical fracturing is found in relatively low and flat topographies with only moderate elevation (5-10 $\mathrm{m})$ in respect to the surrounding areas (Selonen, 1998; Selonen et al., 2011) (Fig. 6E). This terrain covers vast areas and is associated with a dense sheeting close to the terrain surface (Fig. 6F) and, in some rock types, with intense horizontal or subhorizontal penetrative micro fracturing, reaching down to several meters ("open stone" according to the quarrymen), and the uppermost layers can be unusable as natural stone. This type of dense sheeting is relatively prone to glacial plucking and produces low-lying flat areas with little micro topography. The low and flat topographies can be used as indicators for natural stone potential, but must be used with caution because of the dense sheeting close to the terrain surface. This type of rock should however not automatically be excluded in exploration, because the sheeting often becomes more spaced downwards.

Micro topography is a good indicator for the variations of the sheeting and fracturing in the glacially polished and plucked Svecofennian bedrock as well as in the rapakivi granites. Topography, in combination with known geological data, can be used as an important indicator for areas with potential for natural stone in all kinds of geological settings.

\section{Results}

As a result of the study, we have defined a selection of geological and topographical aspects which we find relevant for exploration as they indicate potential areas for natural stone (Table 1). These indicators are based on our work in the highly deformed and metamorphosed post-glacial bedrock of southern, central, and eastern Finland. The work covers the main geological settings and processes, and can have a more general application as shown by other authors, regarding, e.g. metamorphism (cf. Ashmole \& Motloung, 2008) and deformation (cf. Heldal et al., 2008). The aspects are selected as guidelines mainly for exploration of granitic natural stones in glacially abraded areas, but certain aspects (e.g. deformation-related) are relevant for other stone types like marbles and schists. Additional important geological features for exploration in schists and marbles can be found in Heldal \& Lund (2000), Carvalho et al. (2008), and Lopes (2012).

The process of natural stone exploration is often described as a regional study focused on identifying new deposits of natural stone (Shadmon, 1996; Smith, 1999; Selonen et al., 2000; Heldal \& Arvanitides, 2003; Selonen \& Heldal, 2003; Luodes, 2008; Ashmole \& Motloung, 2008; Carvalho et al., 2008). The process includes individual stages of desk study, field mapping, and detailed examination of prospects (Selonen et al., 2000; Luodes, 2008; Ashmole \& Motloung, 2008) (Fig. 7A). The detailed examination comprises detailed mapping (e.g. Härmä et al., 2001; Carvalho et al., 2008), geo radar survey (e.g. Luodes \& Sutinen, 2011), core drilling (e.g. Leinonen, 2005), and sampling (e.g. Luodes, 2008; Ashmole \& Motloung, 2008).

The beginning of the exploration process (desk study and field mapping) can be defined as a reconnaissance phase (e.g. United Nations, 2004) (Fig. 7A). At this phase the aim is to locate areas of enhanced potential on a regional scale as well as to 


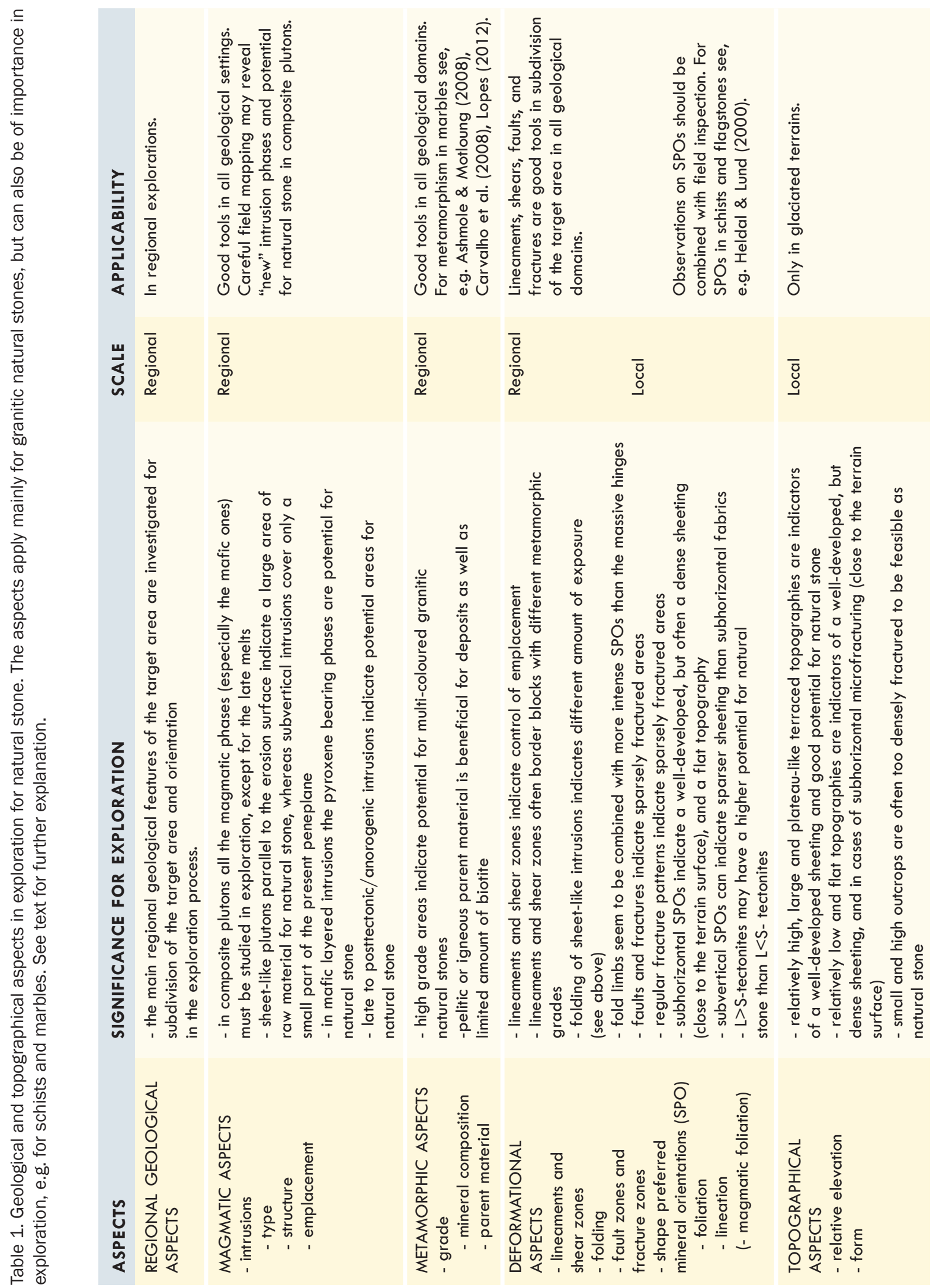


identify areas worthy of further research towards deposit identification.

The aspects proposed in Table 1 can have several applications in exploration for natural stone, especially in the reconnaissance phase (Fig. 7B). In the desk stage all the available material on the target area is collected with the main purpose of reducing the size and number of target areas. These target areas must be defined before field mapping commences because of the high cost of the field work and of the impracticality of mapping the whole target area (Smith, 1999). After this it is possible to direct the exploration to those subareas with the highest potential and to avoid unnecessary field work in areas which clearly hold no potential for natural stone. This makes the exploration more systematic and effective compared to a random areal search practised today.

The planning is mostly based on existing data on the target areas. This data can include published (processed) material like geological maps, studies etc. or unpublished (unprocessed) basic raw data, e.g. geophysical measurements. When we know the geological and topographical aspects indicating the location of natural stone deposits, the right information can be systematically searched for in the published material, focusing the attention on aspects summarized in Table 1 . The list of aspects can serve as a checklist for a systematic searching for potential areas. It is important to combine information from different sources, because localities with good potential for natural stone are situated in areas where several geological (and topographical) constraints overlap.

If previous studies are scarce or missing, the aspects can be used according to the situation. For instance, if there is raw (airborne) geophysical data on the search area, this can be processed to detect,
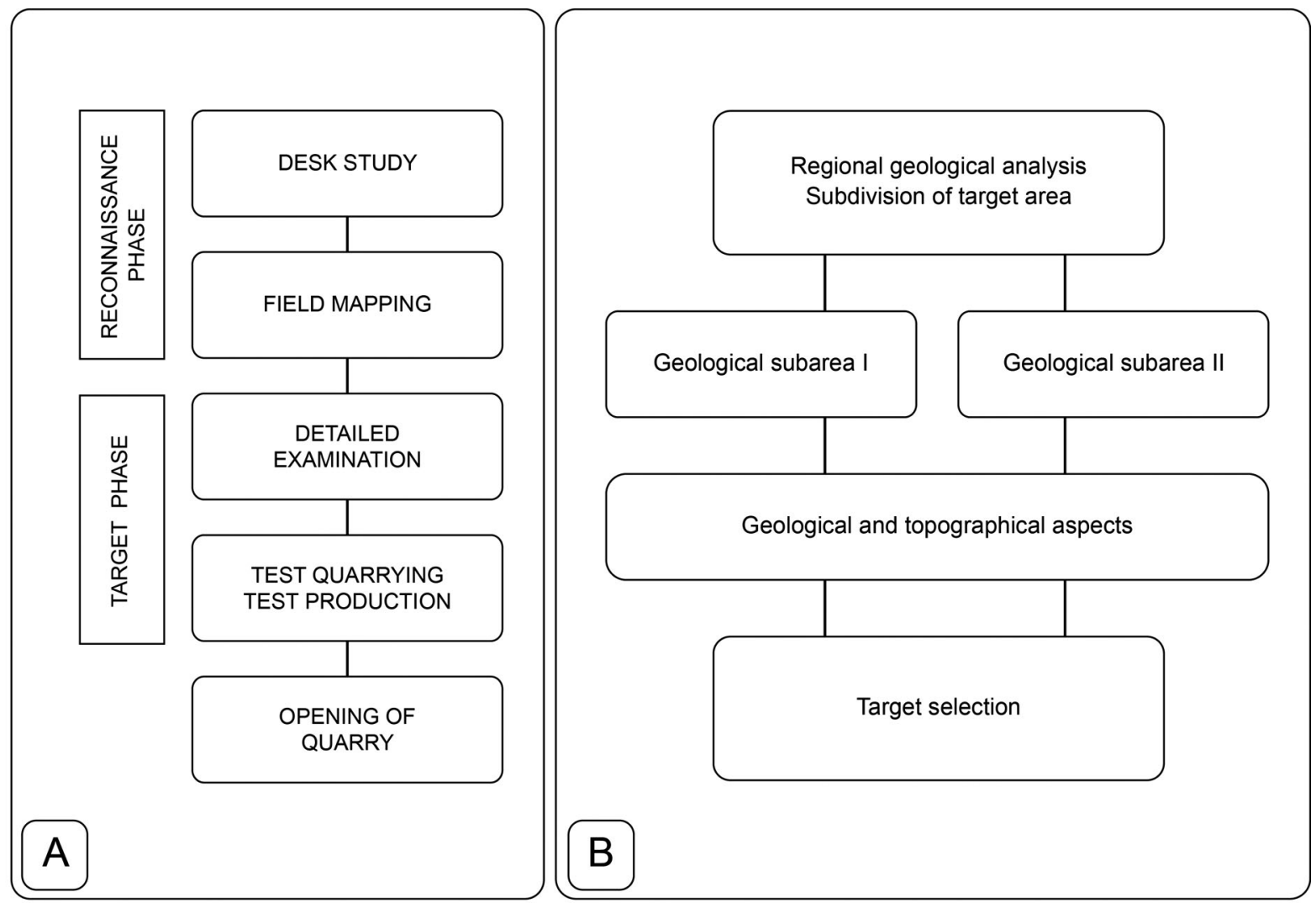

Fig. 7. A model for the exploration process for natural stone (A) (modified from Selonen et al., 2000) and an example of the use of geological and topographical aspects for target selection during the desk stage (B). See text for further explanation. 
e.g. shear zones or intrusion phases which can in turn be used as indicators for potential areas in exploration planning (e.g. Härmä et al., 2013).

In regional explorations with complex geology and several lithologies, the first step in the analysis of the collected material is to identify subareas with potential for natural stone and grade them according to attractiveness (Fig. 7B). Areas of limited interest can be identified and ruled out. In a second step, magmatic, metamorphic, deformational, and topographical aspects (Table 1) are applied in selecting targets for field mapping. An integrated analysis in the second step is essential. In more focused exploration projects, the listed aspects can be selected and applied independently. For instance, in granitoid areas, attention should be focused on the type and structure of intrusions whereas in metamorphic schist belts and migmatites, partial melting and domains of high-grade metamorphism is to be observed. Brittle deformation and topography are observed in all kinds of target areas.

The geological and topographical aspects are also useful in the field mapping, which should include more than just mechanically evaluating the soundness and the homogeneity of appearance on outcrops. Observations of geological (and topographical) features on and around the outcrops, can lead to identification of prospects in a more effective way. For example, structural or magmatic observations can be of great importance, giving indications of geological conditions in near-by (potential) areas. Geological observations on site are especially important in exploration studies, where the existing data on the target area is scarce.

We have applied the aspects listed in Table 1, and found them quite useful during in the reconnaissance phase (e.g. Selonen, 1994; Selonen \& Ehlers, 1998a; Härmä et al., 2006). We have identified areas of enhanced natural stone potential, on a regional scale and in local areas, with features interesting enough for further research. The potential of the areas has been confirmed by subsequent field mapping. In some cases we could identify potential areas down to outcrop scale already during the desk stage. In general, the homogeneity of appearance is more difficult to predict (cf. e.g.
Sousa \& Gonçalves, 2012), and must be finally assessed on the outcrop, but the overall soundness of the bedrock, can in many cases be inferred in an earlier stage of the investigation.

The exploration process in previous papers (e.g. Smith, 1999; Heldal \& Arvanitides, 2003; Ashmole $\&$ Motloung, 2008) is often described as an operation in several stages, but no specific geological aspects to be observed during the process have been determined (cf. Taboada et al.,1999, 2006). By using geological and topographical aspects as suggested in Table 1, the exploration can be more precisely defined, and we can ascribe a tangible geological content to the exploration for natural stone, something that has not been compiled before, only briefly implied by Ashmole \& Motloung (2008).

\section{Exploration for natural stone - science or serendipity}

The quarrymen could (and can) locate natural stone prospects based on their vast experience. However, there must be some implicit geological facts that lead them to the right conclusions. We have identified geological factors constraining the locations of natural stone deposits, and defined geological environments with potential for homogeneous and sparsely fractured rocks suitable for quarrying. Our approach to the study of natural stone is not unlike prospecting for ores, minerals, oil or other natural resources. The geological approach is important, because if we know the most critical factors constraining the locations of existing natural stone occurrences, we will be able to predict geological environments with potential for finding new deposits. We have applied that knowledge to practical exploration work in two ways: (1) by constructing geological exploration models for target areas (e.g. Selonen et al., 2011) and (2) by presenting a list of geological and topographical aspects that we have found useful in prospecting (this paper) in an attempt to be more rational and systematic in our exploration.

Geological understanding can increase the chances of a successful exploration project and even 
a simple working hypothesis concerning the geological evolution of the area, from published and collected material (or compiled during the investigation if there is no previous material), will make the exploration process more precise (particularly in poorly exposed areas). The geological information can be further used in the subsequent detailed examination stage when defining the final production properties of a prospect (cf. Luodes et al., 2000). A structural model can be useful in foreseeing the technical feasibility of a prospect, and later, in explaining the technical properties of the quarried stone (e.g. Heldal et al., 2008).

Geophysical and structural data are particularly informative in exploration. With geophysical data (airborne/ground), previously "unknown" intrusions phases can be revealed (Karell, 2006; Selonen et al., 2011; Härmä et al., 2013) and the distribution of certain rock types (e.g. soapstone and diabase) can be outlined (Luodes, 2008). Topographical data (an elevation model and laser scanning data) can be combined with structural data. This information is helpful in preliminary regional geological studies, and can be utilized in the detailed target exploration (e.g. Selonen \& Heldal, 2003; Härmä et al., 2006; Nyman, 2007; Heldal et al., 2008).

\section{Conclusions}

The location of deposits for natural stone is determined by local and regional geological constraints, and can be studied by geological methods. Knowledge of the geological controls can be applied to practical exploration for natural stone. We have presented a set of magmatic, metamorphic, deformational, and topographical aspects which are relevant in exploration for granitic natural stone. These aspects can be utilized as guidelines for exploration in making prognoses on areas suitable for natural stone and for identifying future prospects in a systematic way based on geological knowledge.

\section{Acknowledgements}

Ms. Kirsti Keskisaari (GTK) and Mr. Harri Kutvonen (GTK) are thanked for preparing maps and figures. We thank Dr. Jorge Carvalho and Dr. Vitali Shekov for critically reading the manuscript and considerably improving the text.

\section{References}

Arponen, E., Härmä, P., Selonen, O. Luodes, H. \& Pokki J. 2009. Anorthosite and spectrolite in the Wiborg rapakivi granite batholith and the lithological control of spectrolite deposits. Geological Survey of Finland, Report of Investigation 178. 41 p. (in Finnish with an English summary).

Ashmole, I. \& Motloung, M. 2008. Dimension stone: the latest trends in exploration and production technology. In: The International Conference on Surface Mining 2008 Challenges, technology, systems and solutions - Papers. The Southern African Institute of Mining and Metallurgy, Johannesburg, Republic of South Africa, pp. 35-70.

Aurola, E. 1967. Building stones of Kuru, Finland. Geological Survey of Finland, Geotechnical publications 71. 64 p. (in Finnish with English summary).

Bradley, F., Founti, M. \& Kontodimos, K., 2004. Commercial characteristics. In: Founti, M. (ed.) Stone for construction and architecture from extraction to the final product. OSNET Editions Volume 10. NTUA, Athens, Greece, pp. 17-26.

Carvalho, J.F., Henriques, P., Falé, P., \& Luís, G. 2008. Decision criteria for the exploration of ornamental-stone deposits: Application to the marbles of the Portuguese Estremoz Anticline. International Journal of Rock Mechanics \& Mining Science 45, 1306-1319.

Cuccuru, S., Casini, L. \& Oggiano, G. 2008. The Giallo S.Giacomo granite: the interplay between quartz LPO and rock behaviour. In: Second International Congress Dimension Stones: XXI Century Challenges. Proceedings, pp. 219-224.

Ehlers, C., Lindroos, A. \& Selonen, O. 1993. The late Svecofennian granite-migmatite zone of southern Finland - a belt of transpressive deformation and granite emplacement. Precambrian Research 64, 295-309.

Egesi, N. \& Tse, C.A. 2011. Dimension stone: exploration, evaluation and exploitation in southwest parts of Oban Massif Southeastern Nigeria. Journal of Geology and Mining Research 3(4), 115-122.

Glazner, A.F., Bartley, J.M., Coleman, D.S., Gray, W. \& Taylor, R.Z., 2004. Are plutons assembled over millions of years by amalgamation from small magma chambers? GSA Today 14 (4/5), 4-11.

Härmä, P. 1987. Keski-Suomen Suomenselän teollisuus- ja rakennuskivitutkimus: loppuraportti. Keski-Suomen maakuntaliitto. Julkaisu 4. Jyväskylä: Keski-Suomen maakuntaliitto. 57 p. +11 app. pages, 2 maps. (in Finnish).

Härmä, P. 1991. Saaren kunnan Lotokanmäen kiviainestutkimukset. Väliraportti. Työ 10218Y00. AIR-IX Suunnittelu Oy. Tampere. 6 p. (in Finnish). 
Härmä, P. 2001. Etelä-Karjalan rakennuskivivarojen etsintäkartoitus 1998-2001. Raportti KA 33/01/2. Geological Survey of Finland. 19 p. (in Finnish).

Härmä, P. \& Selonen, O. 2000. Kymenlaakson rakennuskivivarojen kartoitus. Kymenlaakson liiton julkaisuja B:118. Suomen Kiviteollisuus Oy. Kymenlaakson liitto. 24 p. (in Finnish).

Härmä, P. \& Selonen, O. 2008. Surface weathering of rapakivi granite outcrops - implications for natural stone exploration and quality evaluation. Estonian Journal of Earth Sciences 57, 135-148.

Härmä, P., Selonen, O. \& Luodes, H. 2001. Prospecting of bedrock resources - dimension stones in a rapakivi granite area, a case history. In: Kuula-Väisänen, P. \& Uusinoka, R. (eds.) Proceedings of Aggregate 2001 - Environment and Economy. Helsinki, Finland 6-8 August 2001. Volume 1. Publication number 50 of Tampere University of Technology. Laboratory of engineering geology, pp. 175-179.

Härmä, P., Airo, M.-L. \& Selonen, O. 2013. The use of airborne geophysics in exploration for natural stone. In: Mineral deposits research for a high-tech world. $12^{\text {th }}$ SGA Biennal Meeting 2013. Proceedings. Volume 4, pp. 1796-1798.

Härmä, P., Karttunen, K., Nurmi, H., Nyholm, T., Sipilä, P. \& Vuokko, J. 2006. Natural stone exploration project in the Tampere region 2001-2005. Geological Survey of Finland, Report KA 33/2006/1. 24 p. +8 app. (in Finnish with English summary).

Heldal, T. \& Lund, B. 1995. A regional study of the dimensionstone potential in labradorite-bearing anorthositic rocks in the Rogaland Igneous Complex. NGU Bulletin 427, 123-126.

Heldal, T. \& Lund, B. 2000. Fabrics and structure of metamorphic flagstones and implications for industrial quality. NGU Bulletin 436, 137-146.

Heldal, T. \& Arvanitides, N. 2003. Exploration and prospecting - economic target selection. In: Terezopoulos, N. \& Paspaliaris, I. (eds.) Dimension stone quarrying in Europe and stability of quarrying operations. OSNET Editions Volume 2. NTUA, Athens, Greece, pp. 13-23.

Heldal, T., Kjølle, I., Meyer, G.B. \& Dahlgren, S. 2008. National treasure of global significance. Dimension-stone deposits in larvikite, Oslo igneous province, Norway. Geological Survey of Norway Special Publication 11, 5-18.

Hölttä, P. 1995. Contact metamorphism of the Vaaraslahti pyroxene granitoid intrusion in Pielavesi, Central Finland. In: Relationship of granitoids, structures and metamorphism at the eastern margin of the Central Finland Granitoid Complex. Geological Survey of Finland, Bulletin 382, 27-79.

Ivanov, A.A. \& Shekov, V.A. 2012. Methodological bases of the evaluation of the deposits of a block stone. Mining Journal 5. (in Russian with English summary).

Kähkönen, Y. 2005. Svecofennian supracrustal rocks. In: Lehti- nen, M., Nurmi, P.A. \& Rämö, O.T. (eds.) Precambrian Geology of Finland - Key to the Evolution of the Fennoscandian Shield. Elsevier, Amsterdam, pp. 343-406.

Karell, F. 2006. Magnetic fabric investigation on rapakivi granites in Finland. In: Lithosphere 2006: Fourth Symposium on the Structure, Composition and Evolution of the Lithosphere in Finland, Espoo, November 9-10, 2006: programme and extended abstracts. Institute of Seismology, University of Helsinki. Report S-46, 51-56.

Karell F., Ehlers C., Airo M-L. \& Selonen, O. 2009. Intrusion mechanisms and magnetic fabrics of the Vehmaa rapakivi granite batholith in SW Finland. Geotectonic Research 96 (1), 53-68.

Korsman, K., Niemelä, R., \& Wasenius, P. 1988. Multistage evolution of the Proterozoic crust in the Savo schist belt, eastern Finland. Geological Survey of Finland, Bulletin 343, 89-96.

Leinonen, S. 2005. Diamond drilling and core analysis. Promotion of natural stone industry in the Northern areas PNASTINA. Geological Survey of Finland, Report. 16 p.

Levin, T., Engström, J., Lindroos, A., Baltybaev, S. \& Levchenkov, O. 2005. Late-Svecofennian transpressive deformation in SW Finland - evidence from late-stage D3 structures. GFF 127, 129-137.

Loorents, K.-J. 2000. Sedimentary characteristics, brittle structures and prospecting methods of the flammet quartzite - a feldspacthic metasandstone in industrial use from the Offerdal Nappe, Swedish Caledonides. Academic dissertation. Earth Science Centre. Göteborg University. A48.

Lopes, L. 2012. The geology as an indispensable tool for optimizing the exploration of dimension stones. In: Proceedings of the MERSEM'2012 8th International Marble and Natural Stone Congress, 13-15 Aral1 k/ December 2012, Afyonkarahisar - Turkey.

Luodes, H. 1999. Prospecting for dimension stone in Finland. Roc Maquina 32, 131-132.

Luodes, H. 2003. Exploration of natural stones in Finland. In: Kuula-Väisänen, P. \& Uusinoka, R. (eds.) Workshop on building stones. Helsinki, Finland August 7, 2001. Tampere University of Technology. Laboratory of engineering geology. Report 56, 11-13.

Luodes, H. 2008. Prospecting of new natural stone types in Finland. In: Dimension stones: XXI century challenges. Proceedings of the Second International Congress, May, 29th-31st 2008, Carrara, Italy, pp. 89-93.

Luodes, H. \& Sutinen, H., 2011. Evaluation and modelling of natural stone rock quality using ground penetrating radar (GPR). In: K. Nenonen \& P.A. Nurmi (eds.), Geoscience for Society. $125^{\text {th }}$ Anniversary Volume. Geological Survey of Finland, Special Paper 49, 83-90.

Luodes, H., Selonen, O. \& Pääkkönen, K. 2000. Evaluation of dimension stone in gneissic rocks - a case history from southern Finland. Engineering Geology 58, 209-223. 
Luodes, H., Sutinen, H., Meriluoto, A. \& Vehviläinen A. 2006. Characterization of fracturing in selected rock types with GPR and detailed mapping. In: The 27th Nordic Geological Winter Meeting, January 9-12, 2006, Oulu, Finland : abstract volume. Bulletin of the Geological Society of Finland, Special issue 1, 96.

Meriluoto, A. 2008. Puulan graniitin ja Viipurin rapakivibatoliitin Laapaksen alueen rakennegeologinen tulkinta. MSc thesis, University of Turku, Department of Geology, Geology and Mineralogy, Turku, Finland. (in Finnish).

Nironen, M. 2005. Proterozoic orogenic granitoid rocks. In: Lehtinen, M., Nurmi, P.A. \& Rämö, O.T. (eds.) Precambrian Geology of Finland - Key to the Evolution of the Fennoscandian Shield. Elsevier B.V. Amsterdam, Netherlands, 443-480.

Nironen, M., Elliott, B. A. \& Rämö, O. T. 2000. 1.88-1.87 Ga postkinematic intrusions of the Central Finland Granitoid Complex: a shift from C-type to A-type magmatism during lithospheric convergence. Lithos 53, $37-58$.

Nyman, R. 2007. Geological, geophysical, and structural features of the Kuru batholith. MSc thesis, Åbo Akademi University, Department of geology and mineralogy, Tur$\mathrm{ku}$, Finland.

Přikryl, R, 2006. Assessment of rock geomechanical quality by quantitative rock fabric coefficients: Limitations and possible source of misinterpretations. Engineering Geology 87, 149-162.

Rämö, O.T. \& Haapala, I. 2005. Rapakivi granites. In: Lehtinen, M., Nurmi, P.A. \& Rämö, O.T. (eds.) Precambrian Geology of Finland - Key to the Evolution of the Fennoscandian Shield. Elsevier, Amsterdam, pp. 533-562.

Shadmon, A. 1996. Stone: an introduction. Second edition. Intermediate Technology Publications. London. 172 p.

Shekov, V. 2008. Classification of dimension stone deposits. [Electronic resource]. In: 33rd International Geological Congress, 6-14 August 2008, Oslo, Norway : abstract CDROM. 1 p. Optical disc (CD-ROM).

Selonen, O. 1988. Geologin inom Särkilahti-området, SE Finland. MSc thesis, Åbo Akademi University, Department of geology and mineralogy, Turku, Finland. (in Swedish).

Selonen, O. 1994. K.H. Renlundin säätiön rakennuskivitutkimukset 1982-1993. K.H. Renlund Foundation. Tur$\mathrm{ku}$, Finland. (in Finnish). 43 p.

Selonen, O. 1998. Exploration for Dimension Stone Geological Aspects. Academic dissertation. Åbo Akademi University. Department of Geology and Mineralogy. Tur$\mathrm{ku}$, Finland.

Selonen, O. 2003. Requisites for natural stone. In: Selonen, O. \& Suominen, V. (eds.) Nordic Stone. Geological Science series. Unesco publishing. Paris, France, pp. 1112.

Selonen, O. 2008. Geological constraints on localization of natural stone deposits. In: Wahl, N.A. (ed.) $28^{\text {th }}$ Nordic
Geological Winter Meeting. January 7-10, 2008 Aalborg, Denmark. Abstract volume, Aalborg University, p. 48.

Selonen, O. \& Ehlers, C. 1996. The Orivesi granite batholith, southern central Finland - characteristics and emplacement. Bulletin of the Geological Society of Finland 68, 11-24.

Selonen, O. \& Ehlers, C. 1998a. Vakka-Suomen kallioperä ja rakennuskivet. In: Vakka-Suomen kallioperä- ja ympäristöselvitys. Varsinais-Suomen liitto, pp. 9-19. (in Finnish).

Selonen, O. \& Ehlers, C. 1998b. Structural observations on the Uusikaupunki trondhjemite sheet, SW Finland. GFF 120, 379-382.

Selonen, O. \& Heldal, T. 2003. Technologies. In: Selonen, O. \& Suominen, V. (eds.) Nordic Stone. Geological Science series, UNESCO publishing, Paris, France, pp. 42-50.

Selonen, O., Ehlers, C. \& Lindroos, A. 1996. Structural features and emplacement of the late Svecofennian Perniö granite sheet in southern Finland. Bulletin of the Geological Society of Finland 68, 5-17.

Selonen, O., Luodes, H. \& Ehlers, C. 2000. Exploration for dimensional stone - implications and examples from the Precambrian of southern Finland. Engineering Geology 56, 275-291.

Selonen, O., Ehlers, C., Luodes, H. \& Lerssi, J. 2005. The Vehmaa rapakivi granite batholith - an assemblage of successive intrusions indicating a piston-type collapsing centre. Bulletin of the Geological Society of Finland 77, 65-70.

Selonen, O., Ehlers, C., Luodes, H. \& Karell, F. 2011. Magmatic constraints on localization of natural stone deposits in the Vehmaa rapakivi granite batholith, southwestern Finland. Bulletin of the Geological Society of Finland 83, 25-39.

Selonen, O., Ehlers, C., Härmä, P. \& Nyman, R. 2012. Natural stone deposits in an assemblage of subhorizontal intrusions - The Kuru granite batholith. Bulletin of the Geological Society of Finland 84, 167-174.

Smith, M.R. (ed.) 1999. Stone: Building stone, rock fill and armourstone in construction. Geological Society, London, Engineering Geology Special Publications 16. 478 p.

Sousa, L.M.O. 2010. Evaluation of joints in granitic outcrops for dimension stone exploitation. Quarterly Journal of Engineering Geology and Hydrogeology 43, 85-94.

Sousa, L.M.O. \& Conçalves, B.M.M., 2012. Color assessment of granitic rocks and implications for their ornamental utilization. COLOR research and application 37 (5), 375383.

Stålfors, T. \& Ehlers, C. 2006. Emplacement mechanisms of late-orogenic granites: structural and geochemical evidence from southern Finland. International Journal of Earth Sciences 95, 557-568.

Taboada, J., Vaamonde, A. \& Saavedra, A. 1999. Evaluation of the quality of a granite quarry. Engineering Geology $53,1-11$.

Taboada, J., Ordóñez, C., Saavedra, A. \& Fiestras-Janeiro, G. 
2006. Fuzzy expert system for economic zonation of an ornamental slate deposit. Engineering Geology 84, 220228.

United Nations 2004. Framework Classification for Fossil Energy and Mineral Resources. http://www.unece.org/ energy/se/reserves.html. Visited 7.6.2011.

Uusinoka, R., Grönroos, S., Ihalainen, P. \& Niskanen, P. 1996. Gabbros as dimension stones and aggregates : an example from SE Finland. In: 30th International Geological Congress, Beijing, China, 4-14 August 1996 : abstracts, p. 399.

Väisänen, M., Eklund, O., Lahaye, Y., O’Brien, H., Fröjdö, S., Högdahl, K. \& Lammi, M. 2012. Intra-orogenic Svecofennian magmatism in SW Finland constrained by LA-MC-ICP-MS zircon dating and geochemistry. GFF 134, 99-114. 